\title{
Two genotypic groups of morphologically similar fish trypanosomes from the Okavango Delta, Botswana
}

\author{
Angela J. Davies ${ }^{1, *}$, Wendy Gibson ${ }^{2}$, Vanessa Ferris ${ }^{2}$, Linda Basson ${ }^{3}$, Nico J. Smit ${ }^{4}$ \\ ${ }^{1}$ School of Life Sciences, Kingston University, Penrhyn Road, Kingston upon Thames KT1 2EE, UK \\ ${ }^{2}$ School of Biological Sciences, University of Bristol, Bristol BS8 1UG, UK \\ ${ }^{3}$ Department of Zoology and Entomology, University of the Free State, PO Box 339, Bloemfontein 9300, South Africa \\ ${ }^{4}$ Department of Zoology, Rand Afrikaans University, PO Box 524, Auckland Park 2006, South Africa
}

\begin{abstract}
Blood smears and blood lysate samples from freshwater fishes captured in the Okavango Delta, Botswana, were examined to determine whether their trypanosomes were all Trypanosoma mukasai, a species of supposed broad host specificity and widespread existence across Africa. Trypanosomes and/or babesiosomes occurred in 20/32 blood smears, and morphometric analysis of trypanosomes from 13/32 smears showed features suggestive of T. mukasai, including nuclear indices consistently $>1$. In 16/32 blood lysate samples from which DNA was extracted, trypanosome DNA was detected in 12/16 by PCR (polymerase chain reaction), using trypanosomespecific ssu rRNA gene primers. Two samples positive for trypanosomes in blood smears yielded no amplifiable trypanosome DNA, but 4 samples with no detectable infection in blood smears were positive for trypanosome DNA, suggesting an overall trypanosome prevalence rate of 17/32 (53\%) among fishes and demonstrating the value of PCR in trypanosome recognition. Cloning and sequencing of the 12 amplified fragments revealed 2 genotypic groups among these fish trypanosomes. Group 1 trypanosomes were from cichlids and 3 families of catfishes, Group 2 from 2 types of catfishes. Sequence comparison showed that the consensus Group 1 sequence was most similar to that of Trypanosoma cobitis, representing European fish trypanosomes of the carassii type, while the consensus Group 2 sequence showed similarity with a trypanosome sequence from another African catfish, Clarias angolensis. It was concluded that the identification of T. mukasai remains a problem, but at least 2 genotypic groups of trypanosomes occur in Okavango Delta fishes, and catfishes in this region appear to contain both types.
\end{abstract}

KEY WORDS: Trypanosoma · Fishes · Genotypic groups · Small subunit rRNA gene $\cdot$ Botswana

\section{INTRODUCTION}

Gibson et al. (2005) reported on the ubiquitous nature of fish trypanosomes and the difficulties in differentiating species reliably. Among problems identified in species recognition were the considerable increase in length of fish trypanosomes with age and the existence of pleomorphism in some infections. Using small subunit ribosomal RNA (ssu rRNA) gene sequences, random amplification of polymorphic DNA and phylogenetic analysis, Gibson et al. (2005) determined that all fish trypanosomes examined fell within a broad aquatic clade, together with those from a vari- ety of amphibious vertebrates. Furthermore, within the broad clade, freshwater fish trypanosomes lay within a smaller, single clade, subdivided into 3 groups. The majority of isolates from 14 species of European fishes fell into 2 groups, A (tincae group) and B (carassii group). These genetic groups did not, however, readily tally with species identification based on morphology, or with host fish origin. A third group, C, was of more diverse origin, and included trypanosomes isolated from an imported African catfish.

Difficulties in identification of freshwater fish trypanosomes were further illustrated by Smit et al. (2004). In a study of these flagellates from the panhan- 
dle region of the Okavango Delta, Botswana, they demonstrated morphometrically variable haemoflagellates, even within a single host. However, despite variations in size and staining properties, Smit et al. (2004) suggested that all the Okavango trypanosomes examined might be Trypanosoma mukasai Hoare, 1932, because their nuclear indices (NI values) were consistently $>1$, that is, forward of the mid-line. Their conclusions (Smit et al. 2004) were shaped partly by the work of Baker $(1960,1961)$ and Negm-Eldin $(1997,1998)$. This research was summarised by Smit et al. (2004), but essentially Baker (1960) noted that nuclear position might be an important factor in discriminating the 3 African freshwater fish trypanosome species that he suspected might be valid (T. mukasai, T. toddi Bouet, 1909 and T. tobeyi Dias, 1952). Baker (1960) reported that the nucleus of $T$. mukasai was 'on the average, slightly in front of the mid-point of the body', whereas in $T$. toddi it was central and in $T$. tobeyi it was anterior. Baker (1960) further suggested that T. mukasai and T. tobeyi might prove to be synonyms. Negm-Eldin (1998) subsequently reported that he was able to transmit T. mukasai to a variety of African wild-caught freshwater fishes and, thus, concluded that most records of trypanosomes from fishes across Africa were of this species. One other trypanosome has been named from a wholly freshwater fish in Africa. Pienaar (1962) reported T. clariense Pienaar, 1962 from a sharp tooth catfish, Clarias gariepinus (Burchell, 1822), from the north west province. However, Smit et al. (2004) suggested that the morphometric and staining properties of this trypanosome were such that $T$. clariense might also prove a synonym of $T$. mukasai.

Clearly, there is a problem in identifying Trypanosoma mukasai. To determine whether the trypanosomes found in the Okavango Delta fishes belong to this species, or whether others may exist, sequences from ssu rRNA genes obtained from a variety of samples are here compared using the techniques employed by Gibson et al. (2005).

\section{MATERIALS AND METHODS}

Recent work on the trypanosomes of fishes from the Okavango Delta and elsewhere in Africa identified those hosts most likely to carry haemoflagellates (Negm-Eldin 1997, Smit et al. 2000, 2004); consequently, fishes of the families Cichlidae, Clariidae, Cyprinidae, Mochokidae and Schilbeidae were selected for study.

As described previously (Smit et al. 2004), fishes were collected in the panhandle region of the Okavango Delta using hand, seine, cast and gill nets, or by rod and line, in December 2003 and January 2004. In a mobile field laboratory, fishes were identified accord- ing to Skelton (2001), each was given an identity number (see Table 1), almost all fishes were measured, and they were kept in aerated aquaria containing fresh river water. Fishes were anaesthetised with MS222, heart blood was drawn up with $5 \mathrm{ml}$ glass Pasteur pipettes, and for each fish 2 drops of blood were placed in a vial containing $0.5 \mathrm{ml}$ of lysis buffer $(5.5 \mathrm{M}$ guanidinium thiocyanate, $0.1 \mathrm{M}$ Tris- $\mathrm{HCl} \mathrm{pH} 7.8,0.03 \mathrm{M}$ EDTA, 2\% Triton; Boom et al. 1990) and stored at ambient temperature. In addition, 1 or 2 thin blood films were prepared from each fish, fixed in absolute methanol and stored in dry boxes. Blood lysates and blood films were later dispatched to the appropriate laboratory for further processing.

Blood films were stained with phosphate-buffered Giemsa ( $\mathrm{pH}$ 6.8) and screened for blood parasites with a $\times 100$ oil objective on a Zeiss Axioskop 20 photomicroscope. Microscopic images were captured by digital camera (Nikon DN100) and stored on computer disks; then parasites were measured with an Eclipse Net (Nikon) image analysis package, calibrated to a stage micrometer.

Fish identity numbers allowed blood smears containing trypanosomes to be matched with their respective blood lysate samples. DNA was extracted from blood lysates using standard methods of phenol-chloroform extraction and alcohol precipitation. The purified DNA was used as template for PCR (polymerase chain reaction) using trypanosome-specific ssu rRNA gene primers to amplify across a highly variable region; forward primer D (5'ACCGTTTCGGCTTTTGTTGG) was used in combination with either primer $\mathrm{H}\left(5^{\prime} \mathrm{CGT}\right.$ CAATTTCTTTAAGTTTC) or I (5'GACTACAATGGTCTCTAATC) to amplify fragments of approximately 570 or 330 bp, respectively (Maslov et al. 1996). Amplified fragments were cloned into a suitable plasmid vector (TOPO 2.1, Invitrogen) and sequenced using universal primers. Sequences were compared using DNAman (Lynnon Biosoft).

\section{RESULTS}

Blood smears from 13/32 fishes were found to contain trypanosomes, with hosts falling within the Cichlidae, Clariidae and Mochokidae (Table 1). None of the Cyprinidae or Schilbeidae appeared infected from blood films, but subsequently 1 Schilbe intermedius (Sample 16) proved positive by PCR, indicating that it contained trypanosome DNA. Some fishes (9/32) in 3 families (Cichlidae, Cyprinidae and Mochokidae) were hosts to the apicomplexan Babesiosoma mariae Hoare, 1930, but only 2 fishes (Samples 13 and 25) were observed to contain mixed infections of both trypanosomes and $B$. mariae (Table 1). 
Table 1. Families and species, identity numbers (IDs), numbers caught and length of fishes captured in the Okavango Delta. Numbers of fishes with trypanosomes, babesiosomes, or both, in blood smears

\begin{tabular}{|c|c|c|c|c|c|}
\hline $\begin{array}{l}\text { Families \& species } \\
\text { of fishes }\end{array}$ & $\begin{array}{l}\text { Fish identity } \\
\text { numbers (IDs) }\end{array}$ & $\begin{array}{l}\text { Number } \\
\text { examined }\end{array}$ & $\begin{array}{l}\text { Total length or } \\
\text { length range (mm) }\end{array}$ & $\begin{array}{l}\text { Type of blood } \\
\text { infection }\end{array}$ & $\begin{array}{l}\text { Number } \\
\text { infected }\end{array}$ \\
\hline \multicolumn{6}{|l|}{ Cichlidae } \\
\hline $\begin{array}{l}\text { Oreochromis andersonii } \\
\text { (Castelnau, 1861) }\end{array}$ & 1,5 & 2 & 260 & Trypanosomes & $2 / 2$ \\
\hline $\begin{array}{l}\text { Serranochromis angusticeps } \\
\text { (Boulenger, 1907) }\end{array}$ & 13 & 1 & 280 & Mixed & $1 / 1$ \\
\hline $\begin{array}{l}\text { Serranochromis macrocephalus } \\
\text { (Boulenger, 1899) }\end{array}$ & $\begin{array}{l}12,14,17 \mathrm{a} \\
17 \mathrm{~b}, 18,24\end{array}$ & 6 & $160-300$ & Babesiosoma mariae & $2 / 6$ \\
\hline \multicolumn{6}{|l|}{ Clariidae } \\
\hline $\begin{array}{l}\text { Clarias gariepinus } \\
\text { (Birchell, 1822) }\end{array}$ & $4,11,32$ & 3 & $310-630$ & Trypanosomes & $2 / 3$ \\
\hline $\begin{array}{l}\text { Clarias theodorae } \\
\text { Weber, } 1897\end{array}$ & 3 & 1 & Not recorded & None detected & $0 / 1$ \\
\hline $\begin{array}{l}\text { Cyprinidae } \\
\text { Labeo lunatus } \\
\text { Jubb, } 1963\end{array}$ & 15 & 1 & 350 & B. mariae & $1 / 1$ \\
\hline $\begin{array}{l}\text { Mochokidae } \\
\text { Synodontis nigromaculatus } \\
\text { Boulenger, } 1905\end{array}$ & $\begin{array}{c}2,6-8,19-21 \\
26-31\end{array}$ & 13 & $160-240$ & $\begin{array}{c}\text { Trypanosomes } \\
\text { B. mariae } \\
\text { Mixed }\end{array}$ & $\begin{array}{l}6 / 13 \\
4 / 13 \\
1 / 13\end{array}$ \\
\hline $\begin{array}{l}\text { Synodontis vanderwaali } \\
\text { Skelton \& White, } 1990\end{array}$ & 25 & 1 & 180 & Trypanosomes & $1 / 1$ \\
\hline $\begin{array}{l}\text { Schilbeidae } \\
\text { Schilbe intermedius } \\
\text { Rüppell, } 1832\end{array}$ & $10,16,22,23$ & 4 & $274-270$ & None detected & $0 / 4$ \\
\hline Total & & 32 & & & $20 / 32$ \\
\hline
\end{tabular}

Trypanosomes were variable in staining properties, shape and size. Morphometric analyses, although not as extensive as in a previous study (Smit et al. 2004), still indicated NI values $>1$ (Table 2), suggestive of Trypanosoma mukasai. Samples 1 and 5 (Oreochromis andersonii) contained only small trypanosomes in blood films, resembling the immature stages of T. mukasai (see Baker 1960, Negm-Eldin 1997, 1998) and the small forms seen earlier in Okavango samples (for example, Figs. 1 and 5 in Smith et al. 2004). Samples 30 and 31 (both Synodontis nigromaculatus) contained only larger trypanosomes, indistinguishable

Table 2. Morphometrics of trypanosomes detected in blood smears. MA, midnucleus to anterior; MP, midnucleus to posterior; PK, posterior to kinetoplast; NL, nuclear length; BW, body width; OL, overall length including free flagellum; NI, nuclear index (MP/MA)

\begin{tabular}{|c|c|c|c|c|c|c|c|c|}
\hline \multirow{2}{*}{$\begin{array}{l}\text { Families \& species of } \\
\text { fishes with trypanosomes } \\
\text { (detected in blood smears) }\end{array}$} & \multirow[t]{2}{*}{ Fish IDs } & \multicolumn{7}{|c|}{$\begin{array}{l}\text { Trypanosome morphometrics, mean } \pm \text { SD (range), based on at least } \\
5 \text { specimens per sample }\end{array}$} \\
\hline & & MA & MP & PK & NL & BW & OL & NI \\
\hline \multicolumn{9}{|l|}{ Cichlidae } \\
\hline Oreochromis andersonii & 1,5 & $\begin{array}{c}13.5 \pm 4.5 \\
(7.2-17.1)\end{array}$ & $\begin{array}{c}16.7 \pm 3.5 \\
(12.3-20.9)\end{array}$ & $\begin{array}{c}1.0 \pm 0.1 \\
(0.8-1.1)\end{array}$ & $\begin{array}{c}2.6 \pm 0.3 \\
(2.3-3.1)\end{array}$ & $\begin{array}{c}1.7 \pm 0.6 \\
(1.1-2.7)\end{array}$ & $\begin{array}{c}34.3 \pm 7.9 \\
(23.3-41.3)\end{array}$ & 1.2 \\
\hline Serranochromis angusticeps & 13 & $\begin{array}{l}13.7 \pm 1.6 \\
(11.7-15.6)\end{array}$ & $\begin{array}{l}19.3 \pm 1.6 \\
(17.7-20.8)\end{array}$ & $\begin{array}{l}1.2 \pm 0.4 \\
(0.8-1.7)\end{array}$ & $\begin{array}{c}2.1 \pm 0.4 \\
(1.6-2.8)\end{array}$ & $\begin{array}{c}1.8 \pm 0.2 \\
(1.6-2.1)\end{array}$ & $\begin{array}{l}41.5 \pm 2.1 \\
(39.2-44.3)\end{array}$ & 1.4 \\
\hline \multicolumn{9}{|l|}{ Clariidae } \\
\hline Clarias gariepinus & 4,11 & $\begin{array}{l}14.6 \pm 0.3 \\
(14.3-14.9)\end{array}$ & $\begin{array}{l}17.3 \pm 0.1 \\
(16.9-17.4)\end{array}$ & $\begin{array}{c}1.1 \pm 0.1 \\
(1.0-1.4)\end{array}$ & $\begin{array}{l}3.3 \pm 1.0 \\
(2.2-4.3)\end{array}$ & $\begin{array}{c}1.3 \pm 0.2 \\
(1.1-1.6)\end{array}$ & $\begin{array}{l}37.5 \pm 0.3 \\
(37.1-38.0)\end{array}$ & 1.2 \\
\hline \multicolumn{9}{|l|}{ Mochokidae } \\
\hline Synodontis nigromaculatus & $\begin{array}{l}2,19-21 \\
27,30,31\end{array}$ & $\begin{array}{l}17.0 \pm 1.4 \\
(15.6-18.5)\end{array}$ & $\begin{array}{l}19.4 \pm 1.7 \\
(17.7-21.1)\end{array}$ & $\begin{array}{l}1.2 \pm 0.2 \\
(0.9-1.5)\end{array}$ & $\begin{array}{c}4.4 \pm 0.2 \\
(4.2-4.6)\end{array}$ & $\begin{array}{l}3.4 \pm 0.8 \\
(2.2-4.3)\end{array}$ & $\begin{array}{c}46.5 \pm 3.8 \\
(42.7-50.3)\end{array}$ & 1.1 \\
\hline Synodontis vanderwaali & 25 & $\begin{array}{c}17.1 \pm 1.8 \\
(14.7-18.9)\end{array}$ & $\begin{array}{c}19.7 \pm 4.0 \\
(14.1-22.6)\end{array}$ & $\begin{array}{c}1.5 \pm 0.3 \\
(1.1-1.9)\end{array}$ & $\begin{array}{c}3.5 \pm 0.2 \\
(3.3-3.8)\end{array}$ & $\begin{array}{c}2.0 \pm 0.3 \\
(1.6-2.5)\end{array}$ & $\begin{array}{c}58.0 \pm 5.2 \\
(52.3-63.7)\end{array}$ & 1.2 \\
\hline Total & 13 samples & & & & & & & \\
\hline
\end{tabular}


from the mature forms of $T$. mukasai illustrated by Hoare (1932), Baker (1960) and Negm-Eldin (1997, 1998) and observed previously in Botswana samples (Figs. 2 to 4 in Smit et al. 2004). Trypanosomes morphologically similar to these larger specimens, but slightly more slender and not in such numbers, were also found in Samples 2, 4, 11, 13, 19 to 21, 25 and 27.

DNA was extracted from 16 of the fish blood samples; 12 were positive for trypanosome DNA by PCR using trypanosome-specific ssu rRNA gene primers (Table 3). Four of the PCR positive samples came from fishes with no detectable parasitaemia by examination of blood smears (Samples 3, 6, 16 and 32); on the other hand, trypanosome DNA could not be amplified from the blood samples from 2 trypanosome-positive fishes (Samples 4 and 25). This may reflect the variable quality and amount of DNA obtained from different blood samples, as only the smaller ca. 330 bp ssu rRNA gene fragment could be amplified from some samples, while both the ca. 330 and ca. 570 bp fragments could be amplified from others (see Table 3). The amplified fragments were cloned and sequenced. Clones from Samples 1, 5, 30 and 31 were sequenced in both directions, while single-sequence reads were obtained from 8 other clones and are therefore less reliable. The 12 sequences obtained were aligned and fell into 2 groups differing by 8 point mutations and 3 insertion/deletions (Table 3, Fig. 1). Group 1 contained 7 samples $(1,3,5,13,16,27$ and 32$)$. The sequences from Samples 1 and 5 differed by 2 nucleotides over 570 bp $(0.35 \%)$, and within-group variation was small, with sequences from Samples 3, 16 and 27 identical to that of Sample 5, and a single base difference in the other 2 sequences. Group 2 contained 5 samples $(2,6$,

Table 3. Comparison of positive (+) or negative (-) blood smears and PCR data, the latter from ssu rRNA gene sequence analysis. Length of sequences (bp) and grouping of fish trypanosomes are also reported

\begin{tabular}{|llcccc|}
\hline $\begin{array}{l}\text { Sample } \\
\text { IDs }\end{array}$ & \multicolumn{1}{c}{ Fish species } & Smear & PCR & $\begin{array}{l}\text { Length of } \\
\text { sequence }\end{array}$ & Group \\
\hline 1 & Oreochromis andersonii & + & + & 570 & 1 \\
2 & Synodontis nigromaculatus & + & + & 577 & 2 \\
3 & Clarias theodorae & - & + & 570 & 1 \\
4 & Clarias gariepinus & + & - & - & - \\
5 & O. andersonii & + & + & 570 & 1 \\
6 & S. nigromaculatus & - & + & 336 & 2 \\
11 & C. gariepinus & + & + & 336 & 2 \\
13 & Serranochromis angusticeps & + & + & 329 & 1 \\
16 & Schilbe intermedius & - & + & 570 & 1 \\
25 & S. nigromaculatus & + & - & - & - \\
27 & S. nigromaculatus & + & + & 329 & 1 \\
28 & S. nigromaculatus & - & - & - & - \\
29 & S. nigromaculatus & - & - & - & - \\
30 & S. nigromaculatus & + & + & 577 & 2 \\
31 & S. nigromaculatus & + & + & 577 & 2 \\
32 & C. gariepinus & - & + & 570 & 1 \\
\hline
\end{tabular}

11, 30 and 31). The sequences from Samples 30 and 31 differed by 1 nucleotide over $577 \mathrm{bp}(0.17 \%)$, and each of the sequences from Samples 2, 6 and 11 differed by 1 base from that of Sample 31. The slight difference in length between the Group 1 and 2 sequences (570 bp compared to $577 \mathrm{bp}$ ) was due to 2 insertions.

Comparison of Group 1 and 2 sequences with others in the database showed the closest similarity to ssu rRNA gene sequences from freshwater fish trypanosomes. In particular, the Group 1 sequence was most similar, but not identical, to that of Trypanosoma cobitis (sequence Tcob, Fig. 1) and other European fish trypanosomes of the carassii group (Gibson et al. 2005). The 2 insertions in the Group 2 sequence, as well as a number of point mutations, revealed similarity to the sequence of a trypanosome isolated from an African catfish (Clarias angolensis) (sequence CLAR, Fig. 1); phylogenetic analysis placed CLAR in a distinct clade from the majority of European freshwater fish trypanosomes (see Gibson et al. 2005).

\section{DISCUSSION}

There are difficulties in working with fish populations in the Okavango Delta, not least because of the seasonal nature of its water course and its temporary lagoons (see Smit et al. 2003), but also because of problems in gaining consistent data from this changeable environment. When blood films from fishes were examined in this region in June to July 1999 and June to August 2001 and 2002, trypanosome prevalence fluctuated between 2 and $31 \%$. The current approach, focusing on representatives of fish families considered likely to carry trypanosomes, resulted in a relatively smaller sample size, but also ensured that 17/32 (53\%) of fishes were trypanosome-positive in blood films or by PCR. A change of fishing season (December to January) also appears to have been of benefit. As with trypanosomes, fluctuations in the number of fishes with apicomplexan blood infections are also evident in Okavango Delta samples if past studies (only 1 infected fish known previously) are compared with the current one (9 fishes infected) (see Smit et al. 2000, 2003, 2004).

The trypanosomes and the apicomplexan (Babesiosoma mariae) found in blood films in the present study appeared identical to those previously reported from Okavango Delta fishes (see Smit et al. 2003, 2004), with 2 mixed infections observed. Furthermore, the finding of trypanosome DNA in some 
blood lysates (Samples 3, 6, 16, 32), when no trypanosomes were observed in blood films, indicates the value of PCR methods in detecting a higher prevalence of infection among fishes than could have been estimated from blood films alone. The presence of trypanosome DNA in 1 sample from the catfish Schilbe intermedius (Siluriformes; Schilbeidae) (Sample 16) in the apparent absence of these parasites from blood films, also supports earlier observations that this fish sustains haemoflagellate infections (Smit et al. 2000, 2004).

Although Smit et al. (2004) commented that all trypanosomes seen in Okavango fishes might be Trypanosoma mukasai, they were also concerned about the morphometric variations that they witnessed, observing that molecular sequencing might help determine whether infections were of 1 type. Indeed, the molecular data obtained in the current study broadly suggest 2 groups of trypanosomes among these fishes: Group 1 related to the carassii genotypic group of European freshwater trypanosomes of the Cypriniformes, and Group 2, to a trypanosome obtained from an African catfish (see Gibson et al. 2005). Group 1 trypanosomes were found in the Cichlidae (Oreochromis andersonii and Serranochromis angusticeps), and catfishes (Clarias gariepinus, C. theodorae, Schilbe intermedius and Synodontis nigromaculatus), while Group 2 were detected in 1 C. gariepinus and 4 specimens of S. nigromaculatus.

Blood films matching Lysate Samples 1 and 5 (Group 1) from Oreochromis andersonii contained among the smallest trypanosomes observed in the current material (Table 2). On the other hand, blood films corresponding to Lysate Samples 30 and 31 (Group 2) from Synodontis nigromaculatus had only trypanosomes indistinguishable from mature forms of Trypanosoma mukasai, as illustrated by Hoare (1932), Baker (1960) and NegmEldin $(1997,1998)$. On the basis of this morphology it is tempting to assign Group 2 to T. mukasai. It follows that this would also identify the smaller trypanosomes of Group 1 occurring in the cichlids, not as young forms of T. mukasai, but likely as belonging to another species. However, T. mukasai was originally described from 4
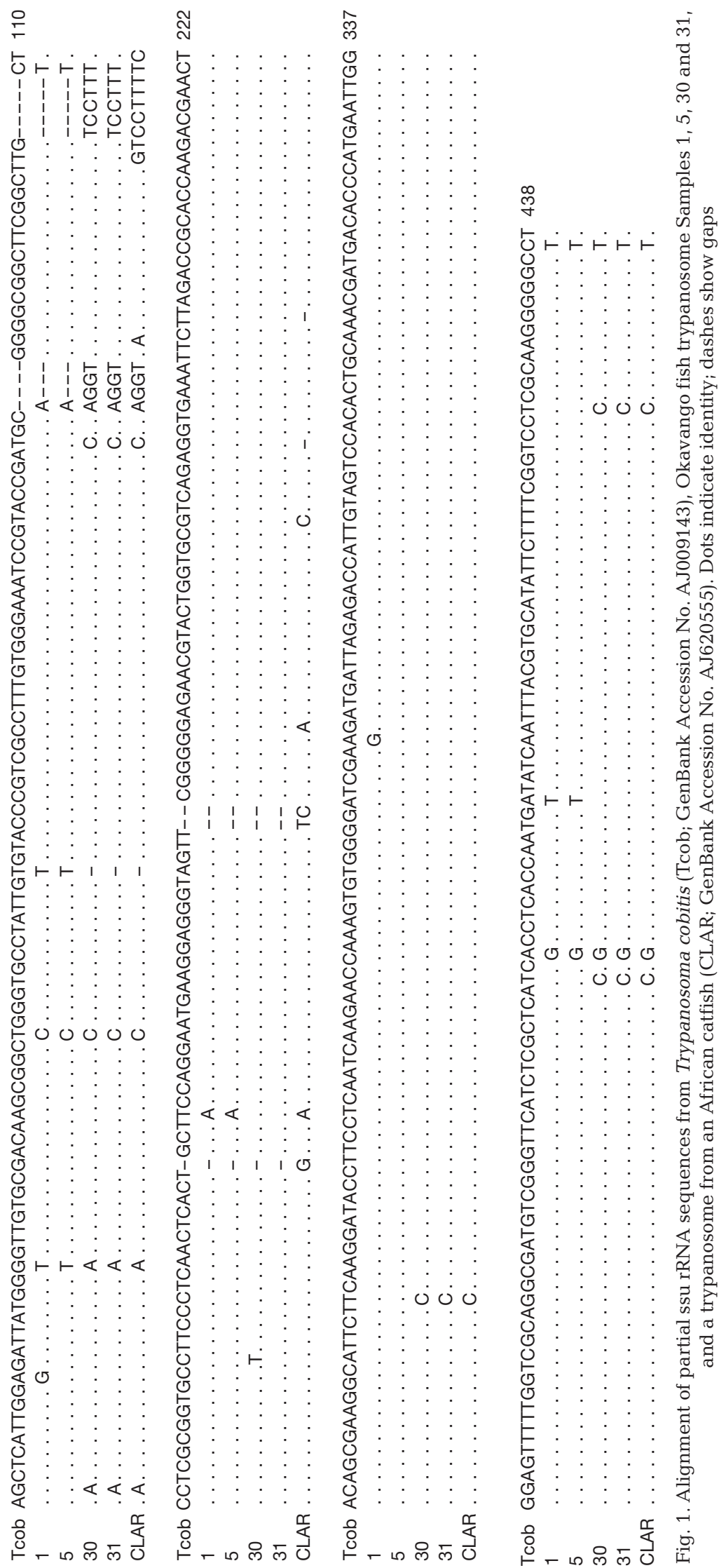
species of cichlids of the genus Haplochromis (see Hoare 1932), and subsequent studies also reported forms indistinguishable from mature stages of the trypanosome within the Cichlidae (Baker 1960, Sinha 1986, Negm-Eldin 1998, Smit et al. 2004).

The Cichlidae (Perciformes) are a very large family of brackish and freshwater fishes distributed over large areas of Africa, South and Central America, all of Madagascar, the Levant, parts of Arabia and India (see Skelton 2001). The 2 cichlid species collected in this study (containing Group 1 trypanosomes) belong to the haplochromine lineage, the species of which tend to be predators, and superficially, at least, these hosts seem to have little in common with the European Cyprinidae. The single cyprinid examined in the current study (Labeo lunatus) appeared to contain only Babesiosoma mariae, but Trypanosoma mukasai apparently can be transmitted to cyprinids and cichlids from the catfish Clarias lazera (see Negm-Eldin 1998). Perhaps, with time, transfer of infection between cyprinids and cichlids has also occurred in the Delta through usage of shared habitats and common vectors, such as leeches. It is also interesting that samples from 3 fishes in which trypanosomes were only demonstrated by PCR, also belonged to Group 1. These included samples from $C$. theodorae (Sample 3), C. gariepinus (Sample 32) and Schilbe intermedius (Sample 16), and all these hosts are catfishes. Thus, trypanosomes of either genotypic group may be found in catfish.

Four trypanosome samples from the Mochokidae (represented by Synodontis nigromaculatus) belonged to Group 2, while a fifth sample belonged to Group 1. The grouping of the majority of Mochokidae samples with others from African catfish in Group 2 is perhaps to be expected, since this family, like the Clariidae, includes catfishes of the order Siluriformes and suborder Siluroidei (see Skelton 2001). Since both catfish and cichlids may be demersal and benthopelagic in distribution (see Skelton 2001), they may share a common population of likely vectors for trypanosomes, such as leeches, as suggested above for the Cyprinidae and Cichlidae.

Clearly, the identity of Trypanosoma mukasai remains a problem, and the unease of Smit et al. (2004) appears well founded. The trypanosome probably does exist in a broad range of fish hosts across Africa (see Negm-Eldin 1998) and likely occurs in India (Sinha 1986). However, not all trypanosomes from freshwater fishes in the Okavango River system appear to be of this 1 species, as 2 distinct genotypic groups of trypanosomes have been identified among the relatively small number of samples collected during the current study. It is possible that some fish harbour both genotypes, leading to the variability in morphology observed in some Okavango samples (see Smit et al. 2004). Both genotypes were found in catfishes in the current study, but cichlids contained only 1 type (Group 1). These differences are difficult to explain, but likely vectors, such as leeches, may perhaps be an additional source of useful sequence data. So far, no leeches have been found on Okavango fishes with trypanosomes, although Batracobdelloides tricarinata (Blanchard, 1897) was identified as a vector of T. mukasai by Negm-Eldin $(1997,1998)$, and this leech can be induced to feed on a wide range of African freshwater fishes (Negm-Eldin 1998).

Acknowledgements. This work was supported, in part, by The Wellcome Trust.

\section{LITERATURE CITED}

Baker JR (1960) Trypanosomes and dactylosomes from the blood of fresh-water fish in East Africa. Parasitology 50: $515-526$

Baker JR (1961) Trypanosomes of African fresh-water fish: an addendum. Parasitology 51:263

Boom R, Sol CJA, Salimans MMM, Jansen CL, Wertheim-van Dillen PME, Van der Noordaa J (1990) Rapid and simple methods for purification of nucleic acids. J Clin Microbiol 28:495-503

Gibson WC, Lom J, Peckova H, Ferris VR, Hamilton PB (2005) Phylogenetic analysis of freshwater fish trypanosomes from Europe using ssu rRNA sequences and random amplification of polymorphic DNA. Parasitology 130: 405-412

Hoare CA (1932) On protozoal blood parasites collected in Uganda, with an account of the life cycle of the crocodile haemogregarine. Parasitology 24:210-224

Maslov DA, Lukes J, Jirku M, Simpson L (1996) Phylogeny of trypanosomes as inferred from the small and large subunit rRNAs: implications for the evolution of parasitism in the trypanosomatid Protozoa. Mol Biochem Parasitol 75:197-205

Negm-Eldin MM (1997) Trypanosoma mukasai (Hoare, 1932) in its biological vector Batracobdelloides tricarinata (Blanchard, 1897) and their life cycles. Dtsch Tieraerztl Wochenschr 104:215-219

Negm-Eldin MM (1998) Further studies on Trypanosoma mukasai Hoare, 1932 and its biological vector Batracobdelloides tricarinata (Blanchard, 1897). Dtsch Tieraerztl Wochenschr 105:175-181

Pienaar UDV (1962) Haematology of some South African reptiles. Witwatersrand University Press, Johannesburg

Sinha CK (1986) Occurrence of Trypanosoma mukasai Hoare, 1932 in Tilapia mossambica (Peters) from India. Acta Protozool 25:449-452

Skelton P (2001) A complete guide to the freshwater fishes of southern Africa. Struik Publishers, Cape Town

Smit NJ, Davies AJ, Van As JG (2000) A trypanosome from the silver catfish (Schilbe intermedius) in the Okavango Delta, Botswana. Bull Eur Assoc Fish Pathol 20:116-119

Smit NJ, Van As JG, Davies AJ (2003) Observations on Babesiosoma mariae (Apicomplexa: Dactylosomatidae) from the Okavango Delta, Botswana. Folia Parasitol 50:85-86

Smit NJ, Van As JG, Davies AJ (2004) Fish trypanosomes from the Okavango Delta, Botswana. Folia Parasitol 51: 299-303

Submitted: January 19, 2005; Accepted: May 3, 2005

Proofs received from author(s): September 20, 2005 